\title{
Leading Factors Contributing to the Generation of Claims in Indian Construction Industry-Consultant's Perception
}

\author{
Mohammed Taha Al-Qershi* and Ravande Kishore \\ Department of Civil Engineering, Osmania University, India
}

Submission: February 24, 2018; Published: April 26, 2018

*Corresponding author: Mohammed Taha Al-Qershi, Department of Civil Engineering, University College of Engineering, Osmania University, Hyderabad, Telangana, India, Email: moh.alqershi@hotmail.com

\begin{abstract}
Claims frequently occur during the course of construction projects in developing countries and Indian construction industry has always been impacted and devastated by excessive number of claims and disputes. This study is investigating the leading factors contributing to the generation of claims and their sources in Indian construction industry. Further, the study is conducted to determine the frequency of occurrence of different claim types in Indian construction projects, and to provide recommendations and suggestions to avoid/mitigate these claims. The objectives of the study have been achieved through a valid questionnaire that was distributed and obtained from different consultant's construction organizations working in Indian construction industry. The results showed that the most important factors that contributed to the generation of claims are contactor financial problem, excessive change orders by owner, slow decisions from owner, poor planning and management by contractor, and delay caused by the contractor. The results also showed that the most frequent claim type is extra-work claim. Several recommendations for the owners and contractors to mitigate claims occurrence are summarized at the end.
\end{abstract}

Keywords: Claim causes; Claim types; Dispute; Mitigate claims; Pivotal position

Abbreviations: DAB: Dispute Adjudication Board; EoT: Extension of Time

\section{Introduction}

Construction Industry plays a key role in the economic development and growth of India and occupies a pivotal position in the nation's development plans. The construction industry is the second largest contributor to the GDP in India after the agriculture sector. According to a report made by CIDC, the construction sector has been contributing around 8 per cent to the nation's GDP. The Indian construction industry is booming, and this is due to a growing economy and demand, interest of foreign investors in India and ongoing major developments in India with more developments to occur in the future [1]. However, this sector contribution is negatively affected by the increasing number of claims as a result of the growing complexity of projects.

Construction industry in most of the countries is infamous for schedule and cost overrun, poor quality, large number of disputes, and many other ills and this is truer in case of developing countries such as India [2]. There are significant time and cost overruns in projects across sectors, which lead to claims. Projects across different government employers suffer from cost overrun of 50$100 \%$, primarily driven by EoT (Extension of time). In the recent years, all of the stakeholders in the construction process have become increasingly concerned with construction claims. That is attributed to the fact that construction claims are found in almost every project. They are indispensable in the construction projects, and mostly in nowadays, where the substantially increasing volume of claims are the result of the rising complexity of the projects, the price structure of construction industry and the legal approach taken by a lot of owners and contractors [3]. In fact, there are few contracts in which there are no claims, negotiations and settlement before the contract is finally closed. However, financially strained Indian construction industry crisis are driven by unsettled claims such as $85 \%$ of claims raised are still pending and average settlement time is nearly 6 to 6.5 years. Employers always take awarded claims to courts to delay payments and courts normally uphold arbitrators' decisions.

It is important to have a staff that can recognize claims at an early stage and know how to deal with them accordingly. Recognizing claims at early stage requires understanding of the major root causes of claims and this understanding must not just be limited to senior management at the home office. Site supervisors and engineers who deal with the day-to-day work 


\section{Civil Engineering Research Journal}

must be 7 equally well informed in how to recognize and identify issues that might give a rise to claims in order to mitigate, avoid or manage them professionally.

Numerous research studies have been conducted on claims and claim management in the developed and developing countries. However, in India enough research studies are not reported on the above stated aspect. Hence there is a need to conduct a research in this area to understand in depth the root factors contributing to the generation of claims in Indian construction industry, to identify the most frequent claim types in Indian construction projects and to assist the professionals in this industry for further development and growth in the management of future projects.

\section{Literature Review}

Scholars through the past years defined claims in different ways. Diekmann and Nelson defined claims as the seeking of consideration or change, or both, by one of the parties to a contract based on an implied or express contract provision [4]. According to Jergeas and Hartman, claim is the application by the contractor for payment that arises other than under the ordinary contract payment provisions [5]. Adrian classified claims into four major types: delay claims, scope of work claims, acceleration claims and changing site conditions claims [6]. Zineldin in his study in the Emirates of Dubai and Abu Dhabi using data from 124 claims, revealed that the types of claims in construction projects in UAE can be classified into six main types: contract ambiguity claims, delay claims, acceleration claims, changes claims, extra-work claims and different site condition claims [7]. Chaphalkar and Iyer in their study of a total of 52 arbitration awards in India found that, out of the 52 arbitration awards, 38 awards are pertained to delay related claims [8]. Chaphalkar and Sandbhor in their study of total 23 arbitration awards for Indian construction projects, a total of 419 claims leading to construction disputes were studied. Nineteen percent of the claims were variation claims, extra-work claims were $17 \%$ and escalation claims were $11 \%$ of the total number of claims studied [9].

Although the available literature review on claims in India is less. The causes of claims have been investigated by many scholars worldwide. Claims for added costs and extended performance time can result from a variety of events during the course of a construction project. The claims may be those of the project owner, the prime contractor or by any of the project's trade contractors or suppliers. Dickmann and Nelson have found that the most common causes for a contract claim are design changes and errors. A comprehensive analysis of claims indicated that $46 \%$ resulted from design errors. An additional $28 \%$ were due to either discretionary or mandatory changes. Thus $72 \%$ of all contract claims can be traced to design changes, extra work, and errors [4]. Zineldin in his study in the Emirates of Dubai and Abu Dhabi using data from 124 claims, revealed that the most frequent causes of claims in construction projects in UAE are: change orders, delay caused by owner, oral change orders by owner, delay in payments by owner [7]. Abd El-Razek et al. [10] reviewed the causes of claims in the international literature and then modified these causes according to the Egyptian construction industry using semi-structured interviews with 10 experts. The modified list included 17 causes. Three case studies were utilized during his research to further investigate the occurrence of each cause in the project. The most frequent causes were: variations initiated by owner/consultant, inferior quality of design, drawings and/or specifications, delays of approval of shop drawings, instructions and decision making and stakeholders involved in the project [10]. Enshassi et al. [11] investigated 41 factors causing claims in Gaza strip, under four categories: owner related factors, design and bill of quantities related factors, contractual relationship related factors, and emergency cases related factors and the results revealed the main causes of claims were awarding bid to the lower bidder, border closures, residents' interference during project implementation and road blockage and difficulties in passing between cities and governorate [11]. Al-Mohsin studied 26 causes of claims in construction industry and collected data from 45 projects with specific criteria in Oman [12]. He divided these factors into four categories based on the origin of claims: owner related factors, consultant related factors, contractor related factors and contract document related factors [12]. Sibanyama et al. [13] during their study on causes of claims in the Zambian construction categorized 20 causes of claims according to the 4 phases of a construction project: pre tender; contract formulation; construction and post construction phases [13]. Mohamed et al. [14] investigated 31 factors causing claims in Egyptian construction industry and concluded that the most disputable claim factors are extension of time, delay interim payment from client, qualification of team work, variations order by owner, poorly written contracts, late supply of equipment and material, incomplete drawings and specification and cooperation and communication nature [14].

\section{Research Methodology}

The work in the present paper was done in two stages, the first stage, 39 claim causes and 8 claim types were identified. The identification was done through a literature review and interviews with experts in Indian construction industry. In the second stage a questionnaire was developed to assess the perception of the consultants towards the factors causing claims and the frequency of different types of claims. The questionnaires were administered through convenience sampling. In convenience sampling, a survey is conducted with respondents who are easily accessible [15]. It is an appropriate method where sufficient information on population size is not available, but like other non probability sampling, findings may not be generalized to the population [16]. The questionnaire is divided into three main parts. Part one is related to general information for both the company and the respondent. Consultants were further requested to answer questions pertaining to their experience in the construction industry, specialization and the size of their 
organizations. The second part of the questionnaire focused on causes of claims, which includes 39 identified causes of claims in Indian construction projects [17]. These causes are classified into the following six major groups according to the source of claim:

\section{Owner/Owner's representative related factors}

Owner personality, delay in handing over site, delay in payments to contractor, lack of staff experience for contract provisions management, excessive change orders by owner, delays of shop drawings approval by owner's representative, delay in approval of completed work, slow decisions from owner, acceleration and stop and go operation, and long line of authority in owner's organization.

\section{Contractor related factors}

Delay caused by contractor, poor planning and management by contractor, contractor's financial problem, poor quality of contractor's work, execution errors by contractor, and lack of control over sub contractor.

\section{Contract documents related factors}

Poorly written contract and ambiguities, variations between original and actual quantities, incomplete contract documents, design error or omissions, and different types of contracts, and discrepancies between contract documents.

\section{Project related factors}

Change scope of the project, different sub grade conditions, complex execution of the project, and change location of the project.

\section{Contractual relationship related factors}

Lack of coordination and communication among parties, failure of participants to deal promptly with changes and unexpected outcome, termination of contract by one of party, suspension of work by one party, awarding bid to lowest bidder, and insufficient time for bid preparation and inadequate investigation before bidding.

\section{External factors}

Force majeure, unexpected changes in exchange, interest, and inflation rate, unexpected change in material price, extreme weather conditions, unforeseen ground condition by all parties, changes in government regulations and laws, and stakeholder (beneficiaries, local community, authorities) interference.

The respondents were asked to indicate the degree of contribution of each factor to the generation of claims in Indian construction industry. The degree of contribution was categorized on a five-point Likert scale as follows: Very high, high, moderate, low, very low, on a 5 to 1 point scale.

Third part of the questionnaire was about the frequency of different types of claims in Indian construction projects. The eight types of claims identified were: Delay claims, changes claims, extra-work claims, different site conditions claims, acceleration claims, disruption claims, contract ambiguity claims and price escalation claims. The respondents were asked to indicate the frequency of occurrence of each type of claim. The frequency was categorized on a five-point Likert scale as follows: Very frequent, frequent, medium, low, rare. On a 5 to 1 point scale.

The respondents were also asked to highlight their recommendations to minimize/mitigate claims in Indian construction industry.

The survey instrument was pilot-tested to measure its validity and reliability. The pilot study was conducted by distributing the questionnaire to two panels of experts having experience in the construction field to assess the questionnaire validity and provide constructive feedback. The first panel, consisting of 8 experts (owners, consultants, contractors), was asked to verify the validity of the questionnaire content and its relevance to the research objective. The second panel, consisting of two experts in statistics, was asked to confirm that the instrument used was valid statistically, and that the questionnaire design was well enough for the purpose of this research. Experts' comments and suggestions were accordingly incorporated to ensure the validity and reliability of the questionnaire.

The research was carried out in India, one hundred and fifty sets of questionnaires were distributed to the potential respondents at all levels in the consultant's organizations within the construction industry, and 89 responses have been received. Though the sample size is relatively small, the quality of the responses was considered to be highly reliable for the analysis due to relevant industry experience.

\section{Data Analysis}

\section{Calculation of relative importance index}

The suggested claim causes and types in Indian construction projects are ranked by the measurement of the relative importance index. The relative index techniques have been widely used in construction research for measuring attitudes with respect to surveyed variables.

Several researchers used the relative importance index in their analysis. Chan \& Kumaraswamy [15] are of the opinion that the mean and standard deviation of each individual factor is not suitable statistics to assess the overall ranking because they do not reflect any relationship between them and accordingly they have used the "relative importance index" (RII) method to determine the relative ranking of factors. The RII is evaluated using the following formula:

Relative Importance Index (RII) $=\frac{\sum W}{A^{*} N}=\frac{(5 n 5+4 n 4+3 n 3+2 n 2+1 n 1)}{5 n}$ (1)

Where $\mathrm{W}$ is the weighting given to each factor by the respondent, ranging from 1 to 5 , (n1=number of respondents for weight $1, \mathrm{n} 2=$ number of respondents for weight $2, \mathrm{n} 3=$ =number of respondents for weight $3, \mathrm{n} 4=$ number of respondents for weight $4, \mathrm{n} 5=$ number of respondents for weight 5). 


\section{Civil Engineering Research Journal}

A is the highest weight (i.e., 5 in the study) and $\mathrm{N}$ is the total number of samples. The relative importance index ranges from 0 to 1 .

\section{Research Results and Discussion}

\section{General characteristics of respondents}

The questionnaire was sent out to a total of 150 consultants, to assess their perception in ranking the identified causes and types of claims in terms of their contribution and frequency using an ordinal scale. A total of 89 filled the questionnaire. The response rate is 59\%. The respondents who are included in the survey have an average of ten years of experience.

Table 1: Relative importance index and ranking of claim causes.

\section{Claim causes}

The causes under each group are ranked by the measurement of relative importance index according to Eq. (1). The ranking of relative importance index of the claim causes in Table 1 shows that contactor financial problem, excessive change orders by owner, slow decisions from owner, poor planning and management by contractor, and delay caused by the contractor are the top significant factors. Moreover, change scope of the project, lack of control over sub contractor, delay in handing over site, variations between original and actual quantities, and poorly written contracts and ambiguities are among the top ten factors. The following is a brief discussion of the ranking of the factors and groups as deducted in Table $1 \& 2$.

\begin{tabular}{|c|c|c|c|}
\hline Category & Causes of Claims & RII\% & Rank \\
\hline \multirow{10}{*}{$\begin{array}{l}\text { Owner/Owner's representative } \\
\text { related factors }\end{array}$} & Owner personality & 58.43 & 34 \\
\hline & Delay in handing over site & 69.66 & 8 \\
\hline & Delay in payments to contractor & 66.07 & 19 \\
\hline & Lack of staff experience for contract provisions management & 64.04 & 24 \\
\hline & Excessive change orders by owner & 72.58 & 2 \\
\hline & Delays of shop drawings approval by owner's representative & 66.74 & 16 \\
\hline & Delay in approval of completed work & 58.65 & 32 \\
\hline & Slow decisions from owner & 72.13 & 3 \\
\hline & Acceleration and stop and go operation & 63.82 & 25 \\
\hline & Long line of authority in owner's organization & 62.92 & 26 \\
\hline \multirow{6}{*}{ Contractor related factors } & Delay caused by contractor & 71.01 & 5 \\
\hline & Poor planning and management by contractor & 71.69 & 4 \\
\hline & Contractor financial problem & 72.81 & 1 \\
\hline & Poor quality of contractor's work & 66.74 & 15 \\
\hline & Execution errors by contractor & 64.04 & 23 \\
\hline & Lack of control over sub contractor & 69.89 & 7 \\
\hline \multirow{6}{*}{ Contract documents related factors } & Poorly written contracts and ambiguities & 69.44 & 10 \\
\hline & Variations between original and actual quantities & 69.66 & 9 \\
\hline & Incomplete contract documents & 66.52 & 18 \\
\hline & Design error or omissions & 68.31 & 13 \\
\hline & Different type of contracts & 55.73 & 36 \\
\hline & Discrepancies between contract documents & 64.27 & 22 \\
\hline \multirow{4}{*}{ Project related factors } & Change scope of the project & 70.11 & 6 \\
\hline & Different sub grade condition & 58.43 & 33 \\
\hline & Complex execution of the project & 64.72 & 21 \\
\hline & Change of project location & 52.58 & 38 \\
\hline \multirow{6}{*}{$\begin{array}{l}\text { Contractual relationship related } \\
\text { factors }\end{array}$} & Lack of coordination and communication among parties & 69.21 & 11 \\
\hline & $\begin{array}{l}\text { Failure of participants to deal promptly with changes and unexpected } \\
\text { outcome }\end{array}$ & 68.99 & 12 \\
\hline & Awarding bid to the lowest bidder & 67.64 & 14 \\
\hline & Termination of contract by one party & 59.1 & 30 \\
\hline & Suspension of work by one party & 62.25 & 28 \\
\hline & $\begin{array}{l}\text { Insufficient time for bid preparation and inadequate investigation before } \\
\text { bidding }\end{array}$ & 66.74 & 17 \\
\hline
\end{tabular}




\section{Civil Engineering Research Journal}

\begin{tabular}{|l|c|c|c|}
\hline \multirow{4}{*}{ External factors } & Force majeure & 51.24 & 39 \\
\cline { 2 - 4 } & Unexpected changes in exchange, interest, and inflation rate & 56.4 & 35 \\
\cline { 2 - 4 } & Unexpected change in material price & 62.25 & 27 \\
\cline { 2 - 4 } & Extreme weather conditions & 54.83 & 37 \\
\cline { 2 - 4 } & Unforeseen ground condition by all parties & 61.8 & 29 \\
\cline { 2 - 4 } & Changes in government regulations and laws & 58.88 & 31 \\
\cline { 2 - 4 } & Stakeholder (beneficiaries, local community, authorities) interference & 64.94 & 20 \\
\hline
\end{tabular}

Table 2: Relative importance index and ranking of major claim causes categories.

\begin{tabular}{|c|c|c|}
\hline Category & RII (\%) & Rank \\
\hline Owner/ Owner's representative related factors & 65.51 & 4 \\
\hline Contractor related factors & 69.36 & 1 \\
\hline Contract documents related factors & 65.66 & 2 \\
\hline Project related factors1 & 61.46 & 5 \\
\hline Contractual relationship related factors & 65.66 & 3 \\
\hline External factors & 58.62 & 6 \\
\hline
\end{tabular}

Owner/Owner's representative related factors: The result shows that the average of this group relative importance index is (RII=65.51\%) with the fourth position of the rank order among the six groups as shown in Table 2. The top ranked factors are: Excessive change orders by owner, slow decisions from owner, and delay in handing over site.

Excessive change orders by owner ranked as the second most critical source of claims. The respondents agreed that excessive change orders by owner during project implementation is considered as one of the main sources of claims caused by owners. An excessive number of changes can disrupt a project and may require a significant change to the contractor's means and methods of performing the work. With excessive changes, the work scope may no longer closely resemble the original contract work scope and the contractor will have to expend additional time and resources to perform the changed work. Therefore, the contractor will seek compensation for the losses incurred due to the changes.

Slow decisions from owners is one of the significant factors which rated at the sixth position. In most cases, slow decisions from owner, is due to lack of proper coordination and communication between owner and consultant or owner and contractor. So in this group the contractor's respondents showed the high significance of this factor in causing claims.

Consultants considered delay in handing over site as one of the major issues in Indian construction projects. Most of the respondents agreed to consider this factor as one of the highest contributing factors to the generation of claims in Indian construction projects.

The bottom ranked factors were: Long line of authority in owner organization, acceleration and stop and go operation, delay in approval of completed work, owner personality, and lack of staff experience for contract provisions management. Most contractor's respondents agreed that these factors have a moderate impact and contribution to the generation of claims in Indian construction industry.

Contractor related factors: Contractor related factors were the highest ranked group with an average relative importance index value of $(\mathrm{RII}=69.39 \%)$ as shown in Table 2 . This group is considered as the highest contributing group to the generation of claims in Indian construction projects from the consultant's perspective.

The respondents measured contractor's financial problem during project implementation as the number one source of claims caused by contractor from the consultant's perspective. Most consultants agreed that this issue affects the performance of the projects and results in delay of the work progress and poor quality performance. So in this group the consultants showed the very important role of this factor in causing claims. Where it directs the contractor and the owner to present claims against each other.

Poor planning and management by contractor rated fourth. Some contractors hastily submit a plan of operation that their field personnel do not intend to follow. What these contractors do not realize that this schedule may be critical in demonstrating the impact of a delay or disruption. In fact, an approved "fictitious" as planned schedule may handicap the contractor's chances of discovering the impact, communicating to the owner resolving the claim, or recovering its unanticipated delay costs if the delay ends up as a dispute.

The respondents ranked delay caused by contractor in the fifth position. Many causes contribute in delays caused by contractor; delay caused by supervisor, delay caused by low experience of contract management by contractor, delay in mobilizing resources, delay in materials or equipments procurement or other issues. So the consultants agreed strongly for this factor results in big problems in construction projects, and if the contractor fails to complete the work in the required time, the owner is entitled 


\section{Civil Engineering Research Journal}

to make a claim against the contractor for additional costs arising out of the contractor-caused delay.

The respondents ranked lack of control over sub contractors at the seventh position. Most consultants agreed that this factor reflects the insufficient management skills of main contractor. This perhaps link to lack of clear contractual framework and objective criteria for engaging subcontractors in Indian construction projects. Lack of control over subcontractor may lead to unwanted conflicts, low productivity and development of negative attitudes on the site, which eventually leads to delays which results in claims.

The latter factors: Poor quality of contractor's work and execution errors by contractor have a relative importance index span ranges from $55 \%$ to $62 \%$ which indicate that these factors have a moderate contribution to the generation of claims.

Contract documents related factors: The results indicate that the average of group 3 relative importance index is (RII=65.66\%) with the third position of the rank order among the six groups. This group is considered as the third highest contributing group to the generation of claims from the consultant's point of view.

Variations in quantities between original and actual quantities was the top ranked factor in this group and is considered as one of the main factors resulting in claims. In large civil engineering projects, variations can be very significant, whereas on small building contracts they may be relatively minor. Variations may give rise to additions or deductions from the contract sum. This may include not just the work which resulted due to the variation, but other expenses that incurred because of the variation, such as the impact on other aspects of the works. Variations may also (but not necessarily) require adjustment of the completion date.

The respondents ranked poorly written contracts and ambiguities at the tenth position. Most consultants agreed that this issue affected them when ambiguities were found in the provisions of their contracts. It was found in some contracts ambiguous provisions led to misunderstanding between contractor and the owner's representative, which will end in a conflict leading to claims submission or disputes between the parties involved in the contract.

The respondents also ranked design error or omission at the thirteenth position. Consultants agreed that this factor has an important role in causing claims in Indian construction projects. Undefined scope from the beginning, frequent changes, and last minute design changes to lower the cost of constructing the project prior to bids opening. In some instances, budget and time constraints force designers to compress design time. Consequently, they may not adequately review the contract drawings or may not have the time or funds to adequately coordinate the work performed by various design disciplines prior to the bidding stage. So all these factors will definitely lead to design errors and omissions and most consultants agreed that this will lead to conflicts between contractor and owner's representative.
Incomplete contract documents, discrepancies between contract documents, and different type of contracts were ranked at the last in this group with relative importance index values ranges from $55 \%$ to $66 \%$ indicating their impact ranges from low to a moderate.

Project related factors: This group of causes have an average relative importance index value of $(\mathrm{RII}=61.46 \%)$ with the fifth position of the rank order among the six groups as shown in Table 2. The top ranked factor in this group is scope change of the project which in overall claim causes ranked at the sixth position. When minor changes in the scope of the work start escalating, the parties must consider whether the contract in essence became a different contract than was originally bargained for and a cardinal change has taken place as this is can be considered one of the main sources of claims in Indian construction industry. Most consultants agreed that "Change scope of the project" affects significantly the project activities and results in delay of work progress and performance.

The latter factors include complex execution of the project, different sub grade condition and change of project location.

Contractual relationship related factors: This group of causes have an average relative importance index value of (RII $=65.66 \%$ ) with the third position of the rank order among the six groups as shown in Table 2.

The top ranked factors in this group are lack of coordination and communication among parties, failure of participants to deal promptly with changes and unexpected outcome, and awarding bid to the lowest bidder. With respect to the first factor, Many contract claims and disputes arise from lack of coordination and good communication between the owner and the contractor or between the contractor and the consultant, subcontractors or suppliers during the time of bidding and during the execution of the project. So in this group the consultants showed this factor as a highly important cause resulting in claims. For the second factor insufficient time for bid preparation and inadequate investigation before bidding. In the current construction industry status in India, with the heavy budgeted and complex projects, changes are inevitable, failure to deal promptly with these changes may lead to big issues and problems that will affect both parties and eventually resulting in claims and disputes.

The respondents ranked awarding bid to the lowest bidder at the fourteenth position So most of the owner's respondents have agreed on the moderate importance of this cause in the creation of claims in Indian construction industry.

The bottom ranked factors were: Insufficient time for bid preparation and inadequate investigation before bidding, suspension of work by one party and termination of contract by one party. The respondents agreed strongly that these factors are moderately contributing to the generation of claims in Indian construction industry. 
External factors: The result shows that the average of group 6 relative importance index value is (RII=58.62\%) with the sixth position of the rank order among the six groups as shown in Table 2. This group is considered as the lowest contributing group to the generation of claims. The top ranked factor in this group stakeholder (beneficiaries, local community, authorities) interference. Consultants considered this factor moderately contributing to the generation of claims in Indian construction projects.

The respondents ranked the following factors: Unexpected change in material price, unforeseen ground condition by all parties, changes in government regulations and laws, unexpected changes in exchange, interest, and inflation rate, extreme weather conditions, and force majeure at the twenty-seventh, twentyninth, thirty-first, thirty-fifth, thirty-seventh, and thirty-minth positions, respectively. Consultants considered these factors of a less importance and contribution in causing claims in Indian construction industry.

\section{Claim types}

The data collected from the third part of the questionnaire were analyzed and the ranking of different types of claim based on their frequency shows the top ranked claim type is extra work claims. This means that extra-work claims are the most frequent type of claims in Indian construction projects from the contractor's point of view. Most of the consultants agreed to consider this claim type as the most frequent claim type in Indian construction projects.

The respondents ranked at the second position delay claims with a relative importance index value of (RII=76.85\%). This indicates that the frequency of occurrence of delay claims in Indian construction projects is high.

Table 3: Relative importance index and ranking of claim types.

\begin{tabular}{|c|c|c|}
\hline Claim Type & RII (\%) & Rank \\
\hline Delay claims & 76.85 & 2 \\
\hline Changes claims & 71.91 & 4 \\
\hline Extra-work claims & 80.22 & 1 \\
\hline $\begin{array}{c}\text { Different site } \\
\text { conditions claims }\end{array}$ & 57.3 & 6 \\
\hline Acceleration claims & 52.81 & 8 \\
\hline Disruption claims & 57.08 & 7 \\
\hline $\begin{array}{c}\text { Contract ambiguity } \\
\text { claims }\end{array}$ & 59.1 & 3 \\
\hline $\begin{array}{c}\text { Price escalation } \\
\text { claims }\end{array}$ & 73.26 & 5 \\
\hline
\end{tabular}

The respondents ranked price escalation claims at the third position with a relative importance index value of (RII=73.26\%) The consultants agreed that this type of claims occurred more frequently in Indian construction projects. The consultants ranked changes claims at the fourth position with a relative importance index value of (RII=71.91\%). Most of the consultants agreed that this type of claims also occurs frequently in Indian construction projects, whereas the respondents ranked different site conditions claims and on the other hand, the respondents agreed to rank contract ambiguity claims, different site conditions claims, disruption claims and acceleration claims at the fifth, sixth seventh and eighth positions, respectively. Most consultant's respondents agreed that these two types of claims have a medium to rare frequency of occurrence in Indian construction projects (Table 3).

\section{Conclusion \& Recommendations}

The paper investigated the causes and the frequency of different types of claims facing the Indian construction industry. A questionnaire was designed and distributed to the consultants. From the results, it was found that the most dominating claim group and source is contractor related factors and the top ten most causes contributing to the generation of claims are: Contactor financial problem, excessive change orders by owner, slow decisions from owner, poor planning and management by contractor, and delay caused by the contractor, change scope of the project, lack of control over sub contractor, delay in handing over site, variations between original and actual quantities, and poorly written contracts and ambiguities. It can also be concluded from this study that extra-work claim is the most frequent claims type in Indian construction industry while delay claims were ranked second, acceleration claims were ranked last, indicating that it is the least frequent claim type in Indian construction projects.

In accordance with these results, the recommendations set out from this research have been derived in a manner which makes them feasible, tangible and can be acquired as steps and procedures. Construction professionals may follow in order to avoid/mitigate and manage their claims. Furthermore, this study was conducted in India and the recommendations maybe generalized to an extent to construction projects within the same industry in India. The essential steps project parties can take to minimize/mitigate claims and deal with the aforementioned identified causes are:

a. Owners should ensure that they understand their duties and obligations under the contract and one of these obligations is to hand over possession of the site to the contractors in a timely manner.

b. Owners and their representatives must define and freeze the scope of the work before tendering the documents. A complete set of plans and specifications with adequate details defining the scope of the project reduces the chances of frequent and subsequent changes and extra work claims.

c. Legal and technical advice should be obtained before entering the contract to ensure that party's interests are properly and adequately reflected in the contract.

d. Owners are advised not to rush the design. They should give the engineering firm and design professionals adequate 


\section{Civil Engineering Research Journal}

time to complete and check and coordinate and complete the design, drawings and specification.

e. Owners are advised to allow sufficient and enough time for bid preparation for the contractors and sub contractors.

f. Allocate risk to the party best able to control and provide equitable rewards for assuming risks.

g. Parties should read, study, review and understand the contract documents.

h. Proper planning for all the project phases shall be prepared at early stage and coordinated with all subcontractors.

i. A dispute adjudication board (DAB) should be established from the beginning of the project.

j. A joint effort between the parties to maintain good coordination and establishing effective communication channels with the all stakeholders throughout the project.

k. Qualified staff in all aspects having a proper knowledge on contract provisions management.

l. Owners are recommended to ensure timely response to the contractor requests regarding information, design clarification, approval of submittals or shop drawings.

m. Owners should regularly and promptly release the bill of payments to the contractors for the work approved by the consultant.

n. Owners are recommended to admit and accept the genuine claims of the contractor at an early stage without further delay, which in turn affects the cash flow of the contractors.

\section{References}

1. Atul A, Skitmore M (2008) Construction Project Management in India. International Journal of Construction Management 8(2): 65-77.

2. Jha, Kumar Neeraj (2013) Determinants of Construction Project Success in India. Springer Dordrecht Heidelberg New York, USA.

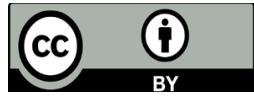

This work is licensed under Creative

Commons Attribution 4.0 License

DOI: 10.19080/CERJ.2018.04.555642
3. Levin (1998) Construction Contract Claims Changes \& Dispute Resolution $\left(2^{\text {nd }} e d n\right)$. Boston: ASCE Press.

4. Diekmann JE, Nelson MC (1985) Construction claims: frequency and severity. Journal of construction Engineering and Management 111(1): 74-81.

5. Jergeas GF, Hartman FT (1994) Contactors' Construction-Claims Avoidance. Journal of Construction Engineering and Management 120(3): 553-561.

6. Adrian JJ (1988) Construction Claims: A Quantitative Approach. Prentice-Hall, New Jersey.

7. Zaneldin E (2006) Construction claims in United Arab Emirates: Types, causes, and frequency. International Journal of Project Management 24(5): 453-459.

8. Chaphalkar N, Iyer KC (2014) Factors Influencing Decisions on Delay Claims in Construction Contracts for Indian Scenario. Australasian Journal of Construction Economics and Building 14(1): 32-44.

9. Chaphalkar NB, Sandbhor Sayali S (2015) Application of Neural Networks in Resolution of Disputes for Escalation Clause Using Neuro-Solutions. KSCE Journal of Civil Engineering, Korean Society of Civil Engineers.

10. Abd El-Razek ME, Bassioni H, Abd El-Salam W (2007) Investigation into the causes of claims in gyptian building construction. In: Boyd D (Ed) Procs 23 ${ }^{\text {rd }}$ Annual ARCOM Conference, pp. 147-156.

11. Enshassi A, Mohamed S, El-Ghandour S (2009) Contractors' Perception towards Causes of Claims in Construction Projects. The International Journal of Construction Management.

12. Al-Mohsin M (2012) Claim Analysis of Construction Projects in Oman. International Journal on Advanced Science Engineering Information Technology 2(2): 2012.

13. Sibanyama G, Muya M, Kaliba C (2012) An Overview Of Construction Claims: A Case Study Of The Zambian Construction Industry. The International Journal of Construction Management 12(1): 65-81.

14. Mohamed H Hossam, Ibrahim H Ahmed, Soliman A Asmaa (2014) Reducing Construction Disputes through Effective Claims Management. American Journal of Civil Engineering and Architecture 2(6): 186-196.

15. Cohen L, Manion L, Marrison K (2006) Research Methods in Education, ( $5^{\text {th }}$ edn), Routledge Publisher, London.

16. Sekaran U, Bougie R (2010) Research Methods for Business: A Skill Building Approach, $5^{\text {th }}$ ed., John Wiley and Sons, Limited, UK.

17. Chan DWM, Kumaraswamy MM (1997) A comprehensive study of causes of time overruns in Hong Kong construction projects. Int J project Management 15(1): 55-63.

\begin{tabular}{l} 
Your next submission with Juniper Publishers \\
will reach you the below assets \\
- Quality Editorial service \\
- Swift Peer Review \\
- Reprints availability \\
- E-prints Service \\
- Manuscript Podcast for convenient understanding \\
- Global attainment for your research \\
- Manuscript accessibility in different formats \\
( Pdf, E-pub, Full Text, Audio) \\
- Unceasing customer service \\
Track the below URL for one-step submission \\
https://juniperpublishers.com/online-submission.php \\
\hline
\end{tabular}

